\title{
Overlever EU?
}

\section{Af Uffe Østergård}

Det bliver stadig tydeligere at EU i kraft af den styrkede nationalisme i øst, vest og nord og kombineret med de nye regionale krav om national selvstændighed vil bevæge sig i retning af et mellemstatsligt samarbejde, støttet af en retsorden beskyttet af en domstol, bliver stadig tydeligere. Det er mindre sikkert, om den nationale egoisme vil ende med at opløse samarbejdet. EU vil sandsynligvis overleve, men det bliver snarere ligesom det Tysk-Romerske Rige, hvis institutioner overlevede helt til 1804.

Den danske debat før nej'et ved folkeafstemningen 3.12.2015 rejste endnu engang det velkendte spørgsmål om samarbejdet skal være mellemstatsligt eller supranationalt? Modstanderne fra Enhedslistens Pernille Skipper til Dansk Folkepartis Morten Messerschmidt hævdede med stor selvsikkerhed at mellemstatslige aftaler virker lige så godt - eller endda bedre - end bindende flertalsafgørelser som de er blevet normen i EU. Uden skyggen af argumentation for påstanden der strider mod al erfaring med internationalt samarbejde i det
20. århundrede fra Folkenes Forbund og FN til Europarådet. Det var netop erfaringerne med de begrænsninger der følger af national suverænitet der lå bag de metoder som har udgjort det særlige ved det europæiske samarbejde fra Kul- og Stålunionen i 1951, over Fællesmarkedet i 1957 til Unionen i 1991 og Lissabon-traktaten i 2009, hvis overnationale principper for politi- og retssamarbejdet var årsag til den danske afstemning om ændring af rets-forbeholdet til en tilvalgsordning (se Jens-Peter Bonde, Hvad stemmer vi om? Retspolitisk Forening, oktober 2015).

Man kan mene meget om ja-sigernes forkølede og ubeslutsomme oplæg og populistiske kampagne, som byggede på den falske lærdom at nej-sigerne plejer at vinde ved at slå på følelser. Hvorefter man fik designet en kampagne med en lyshåret politikvinde i centrum uden argumenter, men fuld af følelsesladede påstande om at et nej betød ja til pædofili. Vælgerne reagerede helt forståeligt på disse påstande. Men købte samtidig en argumentation om national suverænitet som forveksler bevaring af formel suverænitet med den indflydelse som især små og mellem-

Uffe Østergård er professor emeritus i europæisk historie, Department for Business and Politics, CBS og adjungeret professor i moderne europæisk historie, Aarhus Universitet. 
store lande har vundet i EU, netop i kraft af samarbejdets juridiske og forpligtende karakter. Mellemstatsligt samarbejde, som nej-sigerne anbefalede, overlader magten til de store magter, magter der som Storbritannien fejlagtigt tror at de endnu er store, og nogen der som Polen vil anerkendes som store.

Men hele diskussionen byggede på en yderligere misforståelse af hvad samarbejdet har udviklet sig til. EU er nemlig nok ved at blive til en føderation. Men hvis det er en føderation er det som kommissionsformand José Manuel Barroso sagde i sin 'State of the Union' tale til Europa-parlamentet 12. september 2012, en 'føderation af nationalstater'. Det er en logisk modsigelse, men netop derfor en god beskrivelse af nogle af tendenserne i samarbejdet. Ikke det hele, men netop vigtige sider af samarbejdet. Nationalstaterne er nemlig ikke blevet svækkede i EU, selv om både tilhængere og modstandere regnede med at det ville ske og mange påstår det.

\section{Europas 'helgener' - Monnet, Schuman}

I Bruxelles-kredse dyrkes stadig et helt Pantheon af mænd (ingen kvinder) som skabte det europæiske samarbejde. 'Europas helgener' som den britiske historiker Alan Milward maliciøst kaldte dem i 1992. Det drejer sig om den gruppe af realistiske idealister der udviklede de forpligtende samarbejdsmåder der gjorde EU til en stor succes de første 50 år. Og som nu mødes med stadig stigende kritik eller bare ligegyldighed blandt vælgerne. En af dem er den franske udenrigsminister Robert Schuman der 9. maj 1950 proklamerede planen om at bringe "hele den franske og tyske kul- og stålproduktion ind under en fælles 'Høj Myndighed' inden for rammerne af en organisation, der skal være åben for deltagelse af de andre lande i Europa". Det blev til Kulog Stålunionen, det første af de Europæiske Fællesskaber. Schuman var født 1886 i Luxembourg og voksede op i Alsace og Lorraine, mens provinserne var under tysk herredømme. Han studerede jura ved universitetet i Strasbourg og talte således flydende tysk, gjorde karriere som fransk politiker efter 1918 for det kristeligt demokratiske parti, MRP, bl.a. som udenrigsminister 1948-53 og stod for udsoningen mellem Frankrig og Tyskland. Denne indsats er grunden til at han har fået Place Schuman ved Kommissionens Berlaymont-bygning opkaldt efter sig. Godt nok primært en underjordisk u-banestation, men alligevel en plads.

Den anden 'helgen', Jean Monnet, levede fra 1888 til 1979, men mere anonymt. Han var hjernen bag initiativet til samarbejdet og havde indhøstet erfaringer med internationalt samarbejde på administrativt plan under Første Verdenskrig og siden som vicegeneralsekretær i Folkenes Forbund 1919-23. Derefter måtte han for en tid tage sig af familiens cognacfirma på fuld tid, samtidig med at han opererede som international finansekspert. Under Anden Verdenskrig tilsluttede han sig general de Gaulles Frie Franske og organiserede den amerikanske hjælp til Storbritanniens krigsindsats. Efter krigen udarbejdede han den såkaldte Monnet-plan for genopbygningen af Frankrigs økonomi. 1952-54 var han præsident for den Europæiske Kul- og Stålunion, men har ellers primært fungeret bag kulisserne som støber af kugler til det europæiske samarbejde. Samarbejdet var for ham kun et middel, ikke et mål, hvorfor han i november 1954 trådte tilbage fra den Høje Autoritet og i oktober 1955 oprettede en tværnational pres- 
sionsgruppe med det imponerende navn Aktionskomitéen for Europas Forenede Stater. Monnet har mere end nogen anden enkeltperson ansvaret for det europæiske samarbejde, som det ser ud i dag. Men den misforståelige sprogbrug han valgte, har på den anden side også bidraget til den næsten uoverstigelige politiske kløft mellem tilhængere og modstandere af samarbejdet i Europa og den manglende legitimitet i befolkningerne.

Monnets valg af navn var så meget mere underligt - og uheldigt - som han mindst af nogen ønskede at nationalstaterne skulle forsvinde. Han var født fransk og forblev det hele sit liv, selv om han i modsætning til flertallet af sin generation af franske var i stand til at udtrykke sig på engelsk. Han ønskede samarbejdet for at redde nationalstaterne fra deres indbyggede destruktionspotentiale, som han havde haft så privilegeret en udsigt til siden Første Verdenskrig. Set fra Nordeuropa er det i vid udstrækning spændingen mellem den reelle stærke stilling for nationalstaterne i samarbejdet og retorikken om en stadig tættere union mellem Europas folk der er skyld i miseren. Især lutheranere generes af de store ord, mens de latinske politiske kulturer tager forskellen mere koldsindigt, vant som de er til at skelne mellem ord og realiteter og i øvrigt følge egne og familiens interesser.

\section{Europæerne Churchill og de Gaulle}

Spændingen mellem overskrift og reelt indhold var indbygget i samarbejdet fra første færd. Bortset fra den i EU sammenhæng irrelevante flamske latinske filolog, Justus Lipsius, der har givet navn til det Europæiske Råds skumle kolos af en bygning, er de hovedansvarlige for samarbejdet den tysk uddanne- de franskmand Robert Schuman, den engelsktalende franskmand Jean Monnet, samt forløberen for dem alle, frankernes konge og første vesteuropæiske kejser Karl den Store (Carolus Magnus på latin, Charlemagne på fransk) der levede 742-814. Det komplette Pantheon omfatter dog mange flere, som - endnu ikke har fået pladser eller bygninger opkaldt efter sig. De vigtigste er den tyske kansler Konrad Adenauer og den italienske ministerpræsident Alcide De Gasperi. Det var af stor betydning for det tidlige samarbejde at såvel Schuman som De Gasperi fra Trentino, der hørte under Østrig-Ungarn til 1918, var i stand til at forhandle med Adenauer på tysk, samt at Adenauer som rhinlænder havde en større forståelse, også sproglig, for sine franske naboer end flertallet af hans preussiske landsmænd.

Til rækken af afgørende figurer i det europæiske samarbejde hører imidlertid også - og måske især - to politikere der normalt omtales med afsky blandt overbeviste europæere, briten Winston Churchill og franskmanden Charles de Gaulle. De udelades oftest i den officielle historieskrivning om EU, fordi de ikke passer ind i den nemme modstilling af nationalstat og nationalisme på den ene side og supranationalt samarbejde på den anden side. En modstilling, der er populær blandt tilhængere såvel som modstandere af europæisk integration. Uanset at han et helt liv - ja nærmest flere - kæmpede for at opretholde det verdensomspændende britiske imperium uden for Europa, hører Winston Churchill til i kongerækken over store europæere. Det var nemlig ham der 19. september 1946 på universitetet i Zürich proklamerede behovet for 'Europas Forenede Stater' $i$ en tale der næsten har fået samme ver- 
Efter malende at have skildret Europas ruin og slavebinding som følge af Anden Verdenskrig fremsatte Churchill følgende opfordring: "Og dog er der et middel, der, hvis det bliver indført samlet og spontant som et trylleslag, ville forandre hele sceneriet og på få år gøre hele Europa, eller størstedelen af det, lige så frit og lige så lykkeligt, som Schweiz er i dag. Hvad er da dette magtfulde middel? Det er at genskabe den europæiske familie eller så meget af den, vi kan, og give den en struktur, som den kan leve fredeligt, sikkert og frit med. Vi må bygge en slags Europas Forenede Stater."

denshistoriske status som den han tidligere samme år holdt på det lille provinsuniversitet i Fulton, Ohio, hvori han beskrev det jerntæppe der var gået ned midt gennem Europa.

Efter malende at have skildret Europas ruin og slavebinding som følge af Anden Verdenskrig fremsatte Churchill følgende opfordring: "Og dog er der et middel, der, hvis det bliver indført samlet og spontant som et trylleslag, ville forandre hele sceneriet og på få år gøre hele Europa, eller størstedelen af det, lige så frit og lige så lykkeligt, som Schweiz er i dag. Hvad er da dette magtfulde middel? Det er at genskabe den europæiske familie eller så meget af den, vi kan, og give den en struktur, som den kan leve fredeligt, sikkert og frit med. Vi må bygge en slags Europas Forenede Stater." Profetisk - og realistisk - præciserede Churchill sit forslag: "Det første skridt i en genskabelse af den europæiske familie må være et partnerskab mellem Frankrig og Tyskland. Kun på denne måde kan Frankrig genvinde det moralske lederskab i Europa. Der vil ikke komme nogen genoplivelse af Europa uden et åndeligt stærkt Frankrig og et åndeligt stærkt Tyskland. Opbygningen af disse Europas Forenede Stater vil, hvis det gøres ordentligt, være af en sådan karakter, at den gør den enkelte stats materielle styrke mindre væsentlig. Små nationer vil tælle lige så meget som store og kan vinde sig hæder ved at bidrage til den fælles sag."
Det var yderst uklart hvad Churchill egentlig forestillede sig ved Europas Forenede Stater. Vi ved at den kongres der blev indkaldt af Europabevægelserne på britisk initiativ og med talrige nordiske deltagere i Haag 8.-9. maj 1948 resulterede i oprettelsen af Europarådet. Denne hæderværdige organisation har mange kvaliteter, men bygger grundlæggende på respekt for nationalstaternes suverænitet. Derfor holdt Jean Monnet sig væk fra kongressen i Haag som ellers samlede næsten alle europæisk orienterede, også fra Norden. Formodentlig var det netop den føderalistiske idealisme i Europa-bevægelserne, kombineret med en solid skepsis over for Churchills reelle hensigter bag de store ord, der gjorde den pragmatiske Monnet skeptisk. Hans skepsis havde rødder i erfaringen fra juni 1940, hvor han ganske vist havde fået Churchill til at fremsætte forslag om en union mellem Frankrig og Storbritannien efter nederlaget til de tyske hære. Men Churchill så kun unionen som et middel til at bevare Frankrig og især den franske flåde og de franske kolonier i krigen med Tyskland.

\section{Europa for 'de andre'}

Hovedgrunden til at Churchill sjældent indlemmes i rækken af Europas helgenkårede fædre, er at han ikke et øjeblik drømte om at Storbritannien skulle deltage i det europæiske samarbejde. Europa var for ham 'de andre' på Kontinentet, 
mens Storbritannien i hans og flertallet af briternes øjne var centrum i et verdensomspændende imperium, der var alt for stort til Europa. De så det stadig på niveau med fætteren USA, som de ganske vist var kommet økonomisk i lommen på som følge af gældsætningen under Anden Verdenskrig. Men Churchill havde jo bl.a. vundet kampen mod det nazistiske Tyskland ved stædigt at ignorere de objektive kendsgerninger, så den lille detalje om det reelle magtforhold mellem de to sejrende supermagter, USA og Sovjetunionen, på den ene side og Storbritannien på den anden forstyrrede ham ikke. At Storbritannien reelt kun havde valget mellem integration i Europa og positionen som en 'ø vest for Kontinentet' gik først langsomt op for de toneangivende briter efter nederlaget $\mathrm{i}$ Suez 1956 og benægtes tilsyneladende stadig af mindst halvdelen af befolkningen, om end af forskellige årsager som ikke alle skyldes nostalgi efter imperiet, men modvilje mod arbejdskraften fra de nye medlemsstater.

Indlemmer man Churchill blandt Europas 'founding fathers', kommer man imidlertid ikke uden om også at medregne hans nationalistiske alter ego, general de Gaulle. Det gøres dog kun sjældent og da yderst modstræbende af forvalterne af erindringen om integrationsprocessens historie i Bruxelles og omegn. Erindringen om generalens "non" til Storbritannien i 1963 og hans demonstrativt tomme stol i Ministerrådet fra 1965, indtil de andre lande i 1966 accepterede den nationale vetoret, er endnu alt for smerteligt levende. Men i den mere distancerede videnskabelige litteratur er det efterhånden ved at være almindeligt at tage de Gaulle med i rækken af store europæere. I virkeligheden var de Gaulles betydning for det europæiske fællesskab langt fra kun ne- gativ, og det er på mange måder hans vision om 'fædrelandenes Europa' der har sejret.

Desuden var det de Gaulle der gennemtvang den fælles landbrugspolitik fra 1962. I dag er denne politik en dyr klods om benet på EU, selv om den er faldet fra at udgøre 71 pct. af EU's budget til 41 pct. i 2012 og nu også sigter mod naturbeskyttelse og turisme, ikke kun produktion af smørbjerge og vinsøer. Men de aktuelle problemer bør ikke få os til at glemme at denne politik længe udgjorde samarbejdets hårde kerne - selv om det ofte overses at pengene administreres nationalt med deraf følgende mulighed for misbrug i form af ikke eksisterende oliventræer og lignende. Uden den fælles landbrugspolitik ville der ikke have været megen fælles politik i det Europæiske Fællesskab før det indre marked efter 1986, men kun en toldunion som den mellem EFTA-landene. Selv om denne mindre forpligtende konstruktion tilsyneladende svarer bedst til forestillingerne hos flertallet af vælgerne, har EU's mere robuste ordninger med et stærkere supranationalt element i praksis vist sig mere tiltrækkende. Bortset fra ved folkeafstemninger. Her virker formlen en 'føderation af nationalstater' eller bare suveræne nationalstater tilsyneladende bedre.

\section{'En føderation af nationalstater'}

Udtrykket blev ikke opfundet af den tyske grønne udenrigsminister Joschka Fischer. Men det var ham der var ansvarlig for at indførte udtrykket i den europæiske debat. Januar 1999 markerede han begyndelsen på et tysk formandskab ved at præsentere Europaparlamentet for de tyske planer med en diskussion af det - ikke kun i Danmark - ømtålelige spørgsmål om magtfordelingen mellem nationale 
stater og de forskellige EU-organer. Dermed åbnede han for den europæiske forfatningsdebat som i 2004 kulminerede i formuleringen af en Traktat om en forfatning for den Europæiske Union. Fischer tillod sig i talen - om end i yderst diplomatiske vendinger - at sætte spørgsmålstegn ved det, han kaldte den hidtidige EU-metode. Denne fremgangsmåde kaldes på politologisk for neofunktionalisme.

Den neofunktionalistiske teori forklarer integrationen som resultat af såkaldt spill-over fra område til område. Reelt er forklaringen utilstrækkelig. Et kort vue over samarbejdets 65 -årige historie viser at man lige så godt kan tale om fremskridt gennem kriser eller ydre pres. Andre analytikere understreger at samarbejdet foregår mellem stater repræsenteret ved deres regeringer, den såkaldte inter-governmentalisme.

Alt i alt er der ikke tale om særligt imponerende teoridannelser, snarere snusfornuftige beskrivelser af forskellige sider af integrationsprocessen. En af grundene kan være at teorierne er blevet selvopfyldende ved at embedsmændene på universiteterne er blevet undervist i neofunktionalismens antagelser og siden har handlet i overensstemmelse med deres undervisning.

Anden del af Joschka Fischers tale handlede om det demokratiske underskud og den manglende folkelige legitimitet af EU's organer. Bortset fra at hovedparten af det demokratiske underskud skyldes at regeringerne og deres administrationer har øget deres magt på bekostning af parlamenterne var der intet nyt i Fischers kritik. Det nye var at han kaldte støtte- og tilskudsmaskinen for "Monnet-metoden" eller "system Monnet". Denne fremgangsmåde havde efter den tyske regerings opfattelse i
1999 mødt sine grænser og blev i 2014 til program for Jean Claude Junckers Kommission som vil være ambitiøs på store spørgsmål og beskeden i små spørgsmål. (Jacob Langvad, Europas svære fællesskab, 2015, 94).

I en principiel tale på det traditionsrige Humboldt Universitet i Berlin 12. maj 2000 med titlen "Fra statsforbund til føderation" beskrev Fischer nøjere hvad han mente med samarbejdet. I Danmark blev talen misforstået som et traditionelt føderalistisk manifest. Men i dag kan vi se konturerne af en forståelse af det europæiske samarbejde der bygger på nationalstaterne.

Det lille Luxembourg er et godt eksempel. Storhertugdømmet som ikke fik lov til at slutte sig til Tyskland i 1800-tallet, havde tysk og fransk som officielle sprog. Men i 1984 blev dialekten letzeburgisch ophøjet til nationalt sprog og landet har udviklet en national identitet i kraft af EU-samarbejdet - nu med eget universitet efter hidtil at have klaret sig godt med at sende de unge til de bedste universiteter i nabolandene. Selv forbehold har de EU-begejstrede luxembourgere, nemlig en undtagelse fra reglen om at alle EU-borgere har stemmeret ved lokalvalg. Det skyldes angsten for at Luxembourg ville få en borgmester af portugisisk afstamning som efterkommer af portugisere der i 1950erne kom til for at arbejde i den kul- og stålindustri som i mellemtiden er lukket.

Deres efterkommere klarer sig godt og taler letzeburgisch samt tysk, fransk og engelsk. Men sammen med de mange ansatte i de europæiske institutioner kunne de blive flertal i hovedstaden. Derfor forbeholdet i traktaten der nu er lige så veletableret som den danske undtagelse om $\mathrm{k} ø \mathrm{~b}$ af sommerhuse. 


\section{Monnets metode}

Det er i grunden uretfærdigt i dag at kritisere Monnet for den metode han udviklede til at overvinde modstanden i de nationale regeringsapparater helt tilbage $\mathrm{i}$ 1950erne. Men Fischer havde ret i at bringe debatten ud i det åbne. Uanset hvad man mener om argumenterne, er der i dag mere end nogen sinde behov for en åben politisk diskussion om EU's mål og indhold. Svaret er ikke en 'ever closer Union'. Føderalisme er en smuk, men verdensfjern ide, der ikke svarer til det faktiske indhold af EU, som samarbejdet har udviklet sig. På enkelte udvalgte områder som beskyttelse af markedssamarbejdet er reguleringen ganske vist mere vidtgående end i mange stater. Men på de fleste områder er det langt mindre vidtgående eller slet ikke eksisterende. Der er kommet nye områder til, især forsvars- og udenrigspolitik. Men netop fordi disse emner er så følsomme er hovedansvaret placeret i det Europæiske Råd (af regeringsledere), der stort set kun træffer beslutninger enstemmigt.

Monnets metode var skabt til at overliste nationale bureaukratier og snæversynede nationale politikere. På dem har den virket overordentlig godt, ja efter skeptikernes mening alt for godt med de mange reguleringer af detaljer. Problemet er 'bare' at befolkningerne føler sig overlistet. Det er stærkt tvivlsomt om Schengen samarbejdets åbne grænser vil overleve flygtningekrisen samtidig med den udenrigspolitiske udfordring fra Vladimir Putins Rusland, eurokrisen og Grækenlands svage økonomi samt højrepopulismen i Frankrig, Ungarn og nu en nationalkonservativ regering i Polen. Kriserne har overrasket, da det kun er en halv snes år siden at skarpe iagttagere som Mark Leonard og Jeremy Rif- kin skrev entusiastiske bøger om hvordan EU ville vise vej for verden i det 21 . århundrede - underforstået i forhold til mere primitive, magt- og vækstorienterede stater som USA og Kina. Andre fremhævede EU som en enhed der ikke profilerede sig ved hjælp af traditionel magtpolitik, men i stedet satte standarden for normerne i internationalt samarbejde i en stadig mere global verden. En 'normativ magt' blev EU ligefrem kaldt af politologen Ian Manners fra Københavns Universitet. Ganske vist har mere kyniske, primært amerikanske, iagttagere påpeget at EU opførte sig sådan, fordi det var for svagt til at gøre andet. Hvis de da ikke ligefrem, som den amerikanske forsvarsminister Donald Rumsfeld formulerede det, mente at "EU kunne tage opvasken efter de 'rigtige' stormagter havde spist middagen".

Finanskrisen og især krisen for euroen har blotlagt alvorlige svagheder. Det hænger sammen den generelle svækkelse af Europa i forhold til resten af verden. Men denne svækkelse er en langsigtet tendens som har været undervejs i hvert fald siden Anden Verdenskrig. Først i form af afkoloniseringen, der afsluttedes i midten af 1970erne, siden den demografiske udvikling der medfører at de europæiske befolkninger - også i det tidligere kommunistiske Øst- og Centraleuropa - ikke kan reproducere sig selv og derfor bliver stadig ældre. Det har vi vidst længe, men overså det i euforien over genforeningen af kontinentet $\mathrm{i}$ 2004 og den hysteriske optur i det meste af 00’erne. På mange måder burde krisen for euroen ikke undre. Ja man kan sige at den var indbygget i konstruktionen af den Økonomiske og Monetære Union fra begyndelsen i december 1991. For trods titlen var der kun tale om en mone- 
tær, altså pengepolitisk union, mens det var håbet at den økonomiske union ville indfinde sig hen ad vejen i takt med at behovet for afgivelse af økonomisk suverænitet blev indlysende for de deltagende regeringer. Sådan har det europæiske samarbejde med ret stor succes udviklet sig hele tiden siden Kul- og Stålunionen i 1951. Først finanskrisen satte spotlys på de strukturelle problemer med indretning af arbejdsmarkedet, ungdomsarbejdsløshed, tidlig tilbagetrækningsalder og deraf følgende svækket konkurrenceevne. Alt sammen fænomener der hænger sammen med svækkelsen af Europa.

\section{EU og Europas historie}

Men der er tale om en strukturel tilbagegang, som bedst kan forstås ved en sammenligning med den store forskydning efter 1492, da Europa begyndte at ekspandere på bekostning af resten af verden. Opdagelsesrejserne, åbningen af Atlanterhavet og sejlruten til Asien syd om Afrika, flyttede det økonomiske centrum fra Middelhavslandene til Nordvesteuropa, især Nederlandene og England, men også til Nordfrankrig og det vestlige Tyskland. Ja selv Østersølandene profiterede af denne omlægning af handelsruterne. En omlægning der gjorde den danske kongemagt velhavende i et par hundrede år mellem 1410 og 1645, ja i grunden helt til 1807, trods nederlagt til Sverige i 1658.

Indtægterne fra Østersøhandelen gennem Øresund finansierede ikke blot hoffet og pragtslotte, men også den flåde der var forudsætningen for det multinationale imperium, som den oldenborgske stat reelt var. Oldenborgstaten og Vasa-slægtens Sverige var de mest militariserede stater i Europa forstået som militærudgifternes andel af bruttonationalproduktet. Det skyldtes først og fremmest at de var perifere og tyndt befolkede. Men gjorde det altså muligt for 'Danmark' og især 'Sverige' at spille en rolle som europæiske stormagter. For Sveriges vedkommende i stormagtstiden fra 1630 til nederlaget ved Poltava i Ukraine i 1709.

Prisen for den store omlægning af den europæiske økonomi og handelsruterne blev betalt af især Italien, der havde været førende i middelalderen og renæssancen. Relativt set gik først de italienske bystater og siden Spanien tilbage i forhold til Nordvesteuropa. Men netop relativt set. I flere hundrede år, indtil midten af 1700-tallet, registrerede en stormagt som Venezia ikke sit fald i økonomisk indflydelse. Republikken mistede ganske vist sine græske besiddelser til de osmanniske tyrkere, men bevarede alligevel sin diplomatiske og handelsmæssige rolle. For ikke at tale om det årlige karneval, der tiltrak besøgende fra hele Europa. Herunder den danske konge Frederik 4. der i 1708 tog fri fra sin krig med Sverige for at muntre sig i syden. Så skal man dømme ud fra det italienske eksempel, kan det godt lade sig gøre at miste relativ vægt uden dermed nødvendigvis at gå absolut ned i levestandard. Det Europa mister i disse år er evnen til at påtvinge resten af verden vores opfattelse og normer. Men det har som sagt været undervejs i mange år.

Der er gode økonomiske og demografiske årsager til dette tab af indflydelse. EU udgør godt nok et enormt marked endnu, men dets befolkning udgør kun 11 pct. af hele verden og i løbet af en snes år vil det falde til 7 pct. Det har man længe kunnet forudse. Men takket være det europæiske samarbejde lykkedes det at udskyde tabet af indflydelse i verden. Den succes plejer man at forklare med politologiske teorier, hvoraf de mest ro- 
I dag er det dog ikke kun nationalstatslig nationalisme der er på fremmarch, men også nye regionale nationalbevægelser. Bevægelser som den skotske, katalanske og mange andre er ikke tilfredse med blot at opnå regionalt selvstyre indenfor deres 'egne' stater, men vil skrive historien om tilbage til henholdsvis 1714 [Katalonien] og 1707 [Skotland) og blive 'rigtige' nationalstater og fuldgyldige medlemmer af Eப. Det er ikke lykkedes - endnu. Men kravet om fuld selvstændighed foreligger og formuleres stadig kгaftigere, jo mеге det afvises.

buste er den førnævinte neofunktionalistiske spill-over teori. Videnskabeligt blev den formuleret af den tysk-amerikanske politolog Ernst B. Haas i The Uniting of Europe fra 1958 i den første analyse af Kul- og Stålunionen. Den anden teori kaldes inter-governmentalisme og er især forbundet med de amerikanske Harvard politologer Stanley Hoffmann og Andrew Moravcik.

Begge teorier har meget for sig og forklarer forskellige faser i det europæiske samarbejde. Men der er også meget de ikke forklarer, især genopblussen af forskellige former for defensiv nationalisme som følge af krisen og det indre marked for arbejdskraft. Nationalisme er ganske vist ikke noget nyt i EU, men har reelt ledsaget den europæiske integration fra begyndelsen. Så meget at den britiske økonomiske historiker Alan Milward i 1992 ligefrem talte om "the European Rescue of the Nation State" i den gyldne periode fra 1957 til 1973, hvor samarbejdet bragte en umådelig fremgang for befolkningerne i Vesteuropa med sig.

I dag er det dog ikke kun nationalstatslig nationalisme der er på fremmarch, men også nye regionale nationalbevægelser. Bevægelser som den skotske, katalanske og mange andre er ikke tilfredse med blot at opnå regionalt selvstyre indenfor deres 'egne' stater, men vil skrive historien om tilbage til henholdsvis 1714 (Katalonien) og 1707 (Skotland) og blive 'rigtige' nationalstater og fuldgyldige medlemmer af EU. Det er ikke lykkedes
- endnu. Men kravet om fuld selvstændighed foreligger og formuleres stadig kraftigere, jo mere det afvises. Ingen ved hvor disse processer ender. EU er på visse områder en føderation som USA, blot en føderation der er svag udadtil når det gælder fælles udenrigs- og forsvarspolitik, som tydeligt manifesteret i konflikten med Rusland over Ukraine. Men meget mere regulerende på de områder der følger af det indre markeds frie bevægelighed af kapital, arbejdskraft, varer og tjenesteydelser. Især arbejdskraftens frie bevægelighed er et revolutionært princip som aktivistisk fortolket af EU-domstolen i Luxembourg på visse områder overgår USA som forpligtende fællesskab.

Nogen har sammenlignet USA med en appelsin med en hård skal i form af de 23-24 pct. af BNP der forvaltes på føderalt niveau, især militæret, modsat det bløde EU der kun forvalter én pct. i fællesskab. Derved minder USA om det romerske imperium der blomstrede i flere hundrede år med selvstyrende bystater bag en godt forsvaret grænse.

Derimod har vi ikke et historisk forbillede for EU, bortset måske fra Kina i de forskellige perioder hvor landet bestod af konkurrerende stater, før samlingen i 220 f.Kr.. og under opløsningen i 1800 og 1900-tallet. Kina er kommet igen som samlet centralstat $i$ anden halvdel af det 20. århundrede efter denne svaghedsperiode, men om det vil være muligt for Europa på samme måde at udvikle sig til en samlet stat er tvivlsomt, vurderet ud 
fra Europas historiske erfaring der netop er den modsatte, nemlig fraværet af et samlende, universelt imperium. Alene fraværet af et fælles skriftsprog som det kinesiske mandarin der forstås af 98 pct. af den kinesiske befolkning, udgør så stor en forskel at EU som stat kalder på egne teoridannelser.

\section{Føderalisme som EU's religion}

Føderalismen opfattes af mange som en sådan teori. Men den er snarere en ideologi der opererer med et ønsket endemål. Ja, man kan være uærbødig at betragte den som en uerkendt religion for samarbejdet. Det fremgår af en undersøgelse af føderalismens idehistorie. Den ene af Europa-Parlamentets to imposante bygninger i Bruxelles er opkaldt efter den italienske Europa-politiker Altiero Spinelli. Det er på mange måder vel fortjent og berettiget. Spinelli var en af de ledende europæiske føderalister og arbejdede hele sit liv for overnationalt samarbejde under overskriften "Europas Forenede Stater". Han levede fra 1907 til 1986 og sluttede sig 17 år gammel til det kommunistiske parti for at kæmpe mod Mussolinis fascistiske styre i Italien. 1927 blev han arresteret og i slutningen af 1930erne sammen med mange andre antifascister anbragt $i$ isolation (på italiensk confino) på en af de Lipariske Øer, Ventotene, midtvejs mellem Napoli og Sicilien. Dette fængsel kom til at fungere som et veritabelt universitet og politisk udklækningsanstalt for efterkrigstidens politiske elite i Italien, først og fremmest for det lille, men indflydelsesrige, liberaldemokratiske Partito d'Azione der havde sin storhedstid fra 1943 til 1947.

Hovedresultatet var affattelsen af det såkaldte Ventotene-manifest vinteren 1941-42, som skitserede en føderalistisk organisering af Europa efter sejren over nazismen og fascismen. Hovedforfatterne var Ernesto Rossi og Altiero Spinelli. Ad forskellige omveje nåede dette manifest under kampene i Italien til Schweiz, hvor det blev omdøbt til 'Manifest for den europæiske modstandsbevægelse'. Dette dokument blev siden program for den føderalistiske Europabevægelse. Drivkraften bag det europæiske samarbejde, Jean Monnet, hyrede i 1952 Altiero Spinelli til at skrive udkastet til åbningstalen ved det første møde i den 'Høje Myndighed' for Kul- og Stålunionen i august 1952, hvor Monnet for den eneste gang i sit liv arbejdede som lønnet europæisk embedsmand som leder af den Høje Autoritet fra 1952 til 1954 i Luxembourg.

Normalt var Monnets fremgangsmåde at holde sig i baggrunden og arbejde via sine netværk. Det var ikke Spinellis metode, og det kom hurtigt til et brud mellem de to stærke personligheder. Ifølge Spinelli havde Monnet nemlig ingen plan for hvordan man skulle nå frem til en føderation. Helt i overensstemmelse med sin normale fremgangsmåde mente Monnet at "nogle få improviserede idéer" var tilstrækkeligt grundlag. Efter nogle få måneder i Luxembourg vendte Spinelli tilbage til italiensk politik og kom først tilbage i europæisk politik i 1970, da han trods sit nære forhold til det italienske kommunistiske parti, PCI, blev udnævnt til kommissær for industrielle anliggender. Her foretog han igen et overraskende skifte, idet han snart opgav kommissærposten og i stedet lod sig vælge til Europa-Parlamentet, hvor han var afgørende for beslutningen om at indføre direkte valg i 1979. Den beslutning fik skæbnesvangre følger, først i Danmark, siden i lande som Frankrig og Storbritannien, Bulgarien osv. Direkte valgte 
EU-modstandere kunne nemlig med deres EU-midler finansiere modstanderbevægelser uden om de nationale politiske systemer og på den måde vinde national indflydelse.

\section{Demokratisk underskud}

Indførelsen af direkte valg til Parlamentet i 1979 var ment som en 'demokratisk' modydelse for institutionaliseringen af møderne mellem statslederne i det Europæiske Råd i 1974. Det var tanken at Parlamentet skulle udgøre en 'folkelig" modvægt til regeringschefernes topmøder. Men sådan har det mildt sagt ikke fungeret. Det er møder i det Europæiske Råd, der har markeret de store spring fremad i samarbejdet som Maastricht 1991, Amsterdam 1997, København 2002 og Lissabon i 2007. Møderne har selvfølgelig også markeret lavpunkterne for EU, som da Silvio Berlusconi under et topmøde på Korfu fortalte lumre vittigheder og lagde an på de andre regeringschefers overraskede hustruer. Eller Nice 2000, hvor et dårligt forberedt fransk formandskab forkludrede omfordelingen af stemmevægtene i forbindelse med den store udvidelse mod øst og tabte alt på gulvet i nationalistisk iver efter at bevare lige så mange stemmer til Frankrig som til Tyskland.

Hensigten med 1970'ernes reorganisering af samarbejdet var at afbalancere øget inter-governmentalisme, repræsenteret ved det Europæiske Råd, med øget supranationalisme i form af et direkte valgt Europa-Parlament. Siden 1979 har Parlamentet troligt fulgt op på Spinellis oprindelige strategi ved at kræve øget medbestemmelse ved hver traktatændring. $\mathrm{Og}$ trods beklagelser om manglende indflydelse har det haft held til at aftvinge de nationale regeringer øgede indrømmelser i bestandige forsøg på at rette op på det 'demokratiske underskud' i samarbejdet. Problemet er imidlertid at valgdeltagelsen er faldet støt i takt med at Parlamentets indflydelse er steget.

Dette forhold sammen med de uløste problemer omkring lokaliseringen i Strasbourg, Luxembourg og Bruxelles, det svage fremmøde ved plenarmøderne - især den sidste dag i ugen - samt de høje lønninger og eksorbitante rejseafregninger, er det virkelige demokratiske problem i EU. Problemer som næppe rettes op ved øget effektivitet i behandlingen af Kommissionens forslag, selv om der er sket en effektivisering af lovgivningens hastighed. Næppe heller ved at Parlamentet spiller med musklerne, som da det i 1999 truede Santer-kommissionen til at gå af før tiden, eller da det i 2004 afviste en italiener, Rocco Buttiglione, som medlem af Barrosos første kommission på grund af hans holdning til homoseksuelle. Parlamentet er på trods af alt sit gode arbejde åbenbart ikke interessant $\mathrm{i}$ befolkningernes øjne og har ikke formået at vinde afgørende legitimitet.

Den faldende valgdeltagelse ved valgene til Europa-Parlamentet undrer mange professionelle iagttagere. Men den er egentlig en ganske logisk følge af det europæiske samarbejdes natur. Bortset fra den ensartethed der skabes af EU-Domstolens afgørelser på de mange områder som falder inden for Fællesskabets jurisdiktion er EU fundamentalt et samarbejde mellem nationale stater. Man kan oven i købet iagttage en tendens til øget national bevidsthed i de lande der ikke havde en stærkt udviklet national bevidsthed ved begyndelsen af samarbejdet. Kun i ekstremt nationale for nu ikke at sige nationalistiske - lande som Danmark og United Kingdom er der ikke indtruffet en forøgelse af den 
nationale bevidsthed i kraft af samarbejdet. Men det er kun fordi det ikke er muligt at være mere end 100 pct. nationalist. På den baggrund er det i grunden meget forståligt at befolkningerne ikke opfatter Parlamentet som en løsning på EU’s demokratiske underskud, men som en del af det.

At det demokratiske underskud, lige såvel som 'europæiseringen' af regeringerne og især deres embedsmænd, reelt er fænomener i medlemslandene, ændrer ikke ved problemet, men øger det nærmest. I grunden ville det være logisk at vende tilbage til tiden før det direkte valg til Parlamentet, hvor det var sammensat af repræsentanter fra de nationale parlamenter. Det ville understrege EU som et samarbejde mellem nationale stater. Men det er næppe en farbar vej og ikke blot fordi de store og flotte bygninger nu står der, i Bruxelles såvel som Strasbourg. Man kan aldrig gå tilbage til en forladt position. I stedet er der bestræbelser på at inddrage de nationale parlamenter tidligere og mere direkte i lovgivningsprocessen. Det er velment, men strander formentlig på uvilje hos flertallet af parlamentarikere til at sætte sig ind i de enorme mængder af kompliceret regulering der udgør kernen i det europæiske samarbejde.

Så alt tyder på at vi vil blive ved med at halte videre med et Parlament der mødes i fine bygninger i Bruxelles og Strasbourg, og hver måned rejser frem og tilbage med tusindvis af kasser, mens stadig færre vælgere stemmer på det. Det problem afhjælpes næppe af at motorvejen mellem Bruxelles og Strasbourg måske engang bliver repareret færdig. Og heller ikke af at man nu med over 50 års forsinkelse har fået højhastighedstog til Strasbourg - i hvert fald fra den fran- ske side. Det uafklarede forhold mellem inter-governmentalisme og føderalistisk supranationalisme vil leve videre i en usikker balance i det EU, vi stadig ikke kan karakterisere som andet end en UPO, et uidentificeret politisk objekt. Men Parlamentet skulle måske finde sig en anden helt end Spinelli. Hvad med Jens-Peter Bonde, den danske EU-skeptiker der har gjort politisk karriere på at kritisere EU, herunder Parlamentet for manglende demokrati og åbenhed? Han er jo indtil videre den dansker der bedst har markeret sig som europæisk politiker. Selv om han er holdt op som parlamentariker, opererer han stadig på den europæiske politiske scene, nu blot som en åbent formuleret føderalist. Ikke fordi han elsker overnationalt samarbejde for dettes egen skyld, men for at gøre det gennemskueligt og demokratisk.

\section{Nationalisme i EU}

Netop Bondes holdning er på en paradoksal måde bedre i overensstemmelse med den reelle karakter af det europæiske samarbejde end den højtflyvende supranationale idealisme, vi plejer at forbinde med føderalisme. Det er der kommet mærkværdige, skiftende alliancer ud af mellem nordiske venstreorienterede og grønne, franske højreorienterede populister i Front National, excentriske britiske millionærer, katolske fundamentalister fra Polen og bulgarske og rumænske ekstremistiske nationalister. Uanset hvor mærkværdige alliancerne kan forekomme anskuet i en traditionel højre-venstre optik, kan det ikke benægtes at modstanderne af EU ofte opfører sig europæisk, mens de taler nationalt, mens tilhængerne taler europæisk samtidig med at de forfølger nationale interesser.

Der er mange paradokser i europæisk 
samarbejde, men et af de største er at nationalstaterne reelt er blevet styrkede samtidig med at vælgerne frygter at deres nationale suverænitet er ved at forsvinde. Denne fejlagtige tro bliver ikke rigtigere af at mange politikere tror det samme. Det overraskende er nemlig at det europæiske samarbejde reelt har styrket nationalstaterne, så resultatet er blevet det logisk modsigende, en 'Føderation af nationalstater'.

Det er uklart hvem der først fandt på dette modsigelsesfulde begreb. Men det har været i spil siden Joschka Fischers tale på Humboldt universitetet i Berlin 12. maj 2000. Her foreslog han at overvinde den folkelige skepsis over for EU ved at gøre de demokratiske rettigheder klare for befolkningerne i form af en europæisk grundlov. Det førte til Forfatningstraktaten som blev afvist af vælgerne i Nederlandene og Frankrig i 2005.

Fischers tale udløste nemlig en europæisk debat om visioner for Europa som stadig er værd at læse. Allerede 28. maj 2000 meldte den franske premierminister Lionel Jospin sig som tilhænger af formularen en 'Føderation af nationalstater'. Den tyske præsident Johannes Rau fra SPD hævdede på et møde i København i april 2002 at det var ham der først havde fundet på begrebet. Siden har det levet videre og blev blandt andet som før nævint anvendt af kommissionsformand José Manuel Barroso i hans 'State of the Union tale' i Europa-Parlamentet 12. september 2012, hvor han formulerede behovet for en politisk og økonomisk union under denne overskrift.

I al sin logiske modsigelsesfuldhed er begrebet en 'Føderation af nationalstater' både politisk nyttigt fordi det er flertydigt samtidig med at det beskriver den reale - og uforudsete - styrkelse af nati- onalstaterne bedre end mange teoretisk mere tilfredsstillende forklaringer i de politologiske integrationsteorier.

\section{Nationalstater i Europa}

Der er tre hovedtyper af styrkede nationalstater i Europa. For det første de klassiske territoriale stater, hvor en mere eller mindre veldefineret stat eksisterede før det store flertal af indbyggerne blev bevidste om deres fælles nationale identitet, og kom til at tale samme sprog. Disse stater kaldes normalt for statsnationer (engelsk state nations) i den politiske sociologi. Baggrunden for disse territorielle stater var i høj grad krige. Som den historiske sociolog Charles Tilly sagde det i en berømt artikel om statsdannelse fra 1975: "States make war and war makes states". Denne usentimentale påpegning af den tætte sammenhæng mellem krig, tvang og kapital ignorerer religionens helt afgørende betydning for dannelsen af stater i Europa, men har ellers skræmmende meget for sig.

Den anden type af stater er den som især er udforsket af nationalismeforskere, hvor nationale bevægelser 'skabte nationerne' i 1800-tallet og senere. Mange af disse har i dag udviklet sig til nationalt homogene stater baseret på fælles sprog og kultur. "Folkenes ret til national selvbestemmelse" som princippet blev døbt ved fredsslutningerne i Versailles i 191920. Men igen viser en nøjere betragtning at de færreste nationalstater var homogene fra begyndelsen. Mange af dem er blevet det siden, i Øst- og Centraleuropa i høj grad i kraft af Hitlers udryddelser i den nazistiske raceideologis navn og Stalins fordrivelser i den kommunistiske nationalismes navn. Andre steder er den nationale homogenisering sket med mere fredelige midler, især undervisning, mi- 
litærtjeneste, migrationer og massemedier. Det har virket voldsomt på de enkelte mennesker at blive tvunget til at udskifte lokalt sprog og kultur, men de har da normalt bevaret livet.

Endelig er der en tredje vej til nationalstaten, nemlig i kraft af samarbejdet i EU. Det sidste vil nok virke overraskende på mange, tilhængere såvel som modstandere af det europæiske samarbejde, at EU faktisk har stimuleret national identitet $\mathrm{i}$ en række af medlemsstaterne. Det er ikke nemt at få øje på fra gamle og solidt etablerede nationalstater som Storbritannien, Sverige og Danmark. Her var det simpelt hen ikke muligt for den nationale identitet at forøges. Men i mange andre stater er det gået sådan, og nogle kan som Luxembourg faktisk først siges at være blevet nationalstater i kraft af EU. Dertil kommer kravet om nye regionale statsdannelser som dem katalanere og skotter kræver.

Meget tyder derfor på at nationalstaterne vil være med os en rum tid, ja at de vil styrkes. Det skyldes at nationalisme er et umådeligt stærkt princip som på ingen måde synes at svækkes med globaliseringen og internationaliseringen. Tværtimod kan man argumentere for at vi lever $i$ en epoke man kan kalde for den 'globale nationalisme?.

\section{'Getting to Denmark'}

Den udvikling passer den danske stat, med sin blanding af nationalt homogen småstat og arvtager til et multinationalt imperium, som fod i hose. Ganske vist uden at danskerne gør sig det klart eller tør tro på det. Men derved deler vi skæbne med andre afdankede imperier som det britiske. Danmark har bare været småstat så længe at det er lykkedes at høste en række af fordelene ved den mindre stat - 'getting to Denmark' som Francis Fukuyama kalder det i sit nye værk, The Origins of Political Order fra 2011 og 2014. Fukuyama ville oprindeligt have kaldt hele første bind 'Getting to Denmark', men opgav det af salgsmæssige grunde. Men han har bevaret titlen på et underafsnit i bind I. Hans uortodokse fortolkning af Danmark er at det var enevælden der skabte retsstaten med dens ukorrupte embedsstand og at det var forudsætningen for den demokratiske udvikling i 1800- og 1900-tallet, ikke omvendt som det normalt antages.

Historikeren Mette Frisk Jensen har i 2013 overbevisende analyseret hvorledes det danske embedsmandskorps blev renset for korruption i begyndelsen af 1800-tallet. Det førte til en kombination af retsstatens garantier med en høj grad af national identitet og deraf følgende selvsikkerhed. I Danmark forenet i hvad man kan kalde 'ydmyg selvhævdelse'. At denne holdning har styrket den allerede stærke nationale egoisme i medlemsstaterne er klart. Om den vil ende med at opløse samarbejdet er mindre sikkert. Men at EU vil bevæge sig i retning af et mellemstatsligt samarbejde, støttet af en retsorden beskyttet af en domstol, bliver stadig tydeligere i kraft af den styrkede nationalisme i øst, vest og nord, kombineret med de nye regionale krav om national selvstændighed.

EU vil sikkert overleve, men det bliver snarere ligesom det Tysk-Romerske Rige, hvis institutioner overlevede helt til 1804, selv om de blev tømt for betydning i løbet af 1700-tallet. Europa trues af en folkevandring, men det er ikke sikkert at den historiske parallel er Romerrigets undergang i 400-tallet, hvor barbarerne strømmede ind over grænserne, men det mere civiliserede 1700-tal. Det resultere- 
de til gengæld i nationalstater, demokrati og totalitære ideologier i det mørke 20. århundrede. Kort sagt den udvikling som EU var et svar på. Ikke en føderativ stat med klare kompetencefordelinger, men et mudret kompromis som indtil videre bedst dækkes af det selvmodsigende begreb, en føderation af nationalstater.
Med mindre det lykkes en uhellig alliance af Vladimir Putin, Marine le Pen, Viktor Órban, britiske konservative, polske højrepopulister og almindelig ligegyldighed blandt vælgerne helt at få $\mathrm{EU}$ nedlagt.

o 


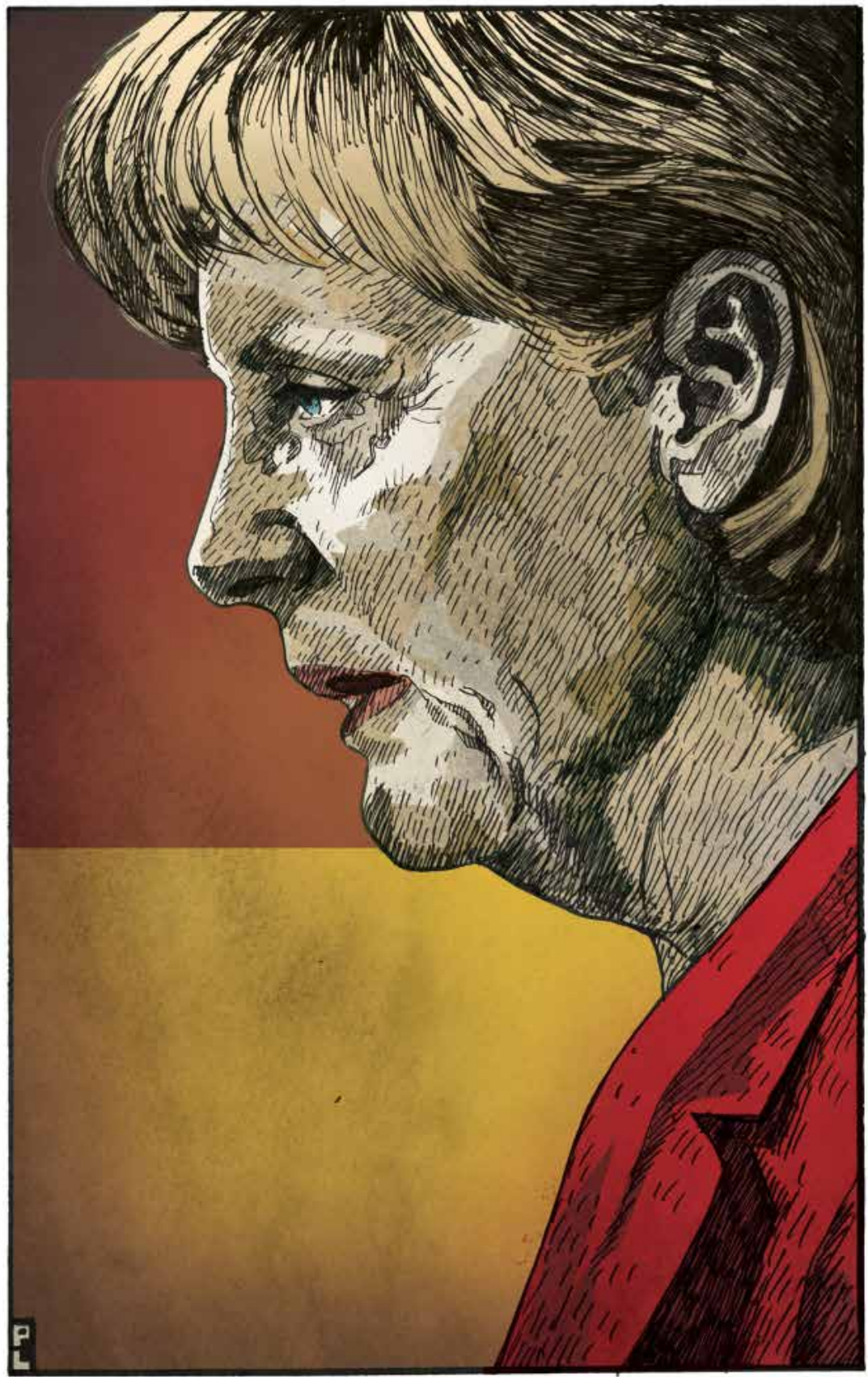

ILLUSTRATION: DProject Syndicate

Mange bekymrer sig om, hvad der vil ske med EU, hvis kansler Angela Merkel efter valget til Forbundsdagen i 2017 skulle forlade tysk politik? 